\title{
Altered expression of an ankyrin-repeat protein results in leaf abnormalities, necrotic lesions, and the elaboration of a systemic signal
}

\author{
Corina Wirdnam ${ }^{1}$, Andrea Motoyama ${ }^{1,2}$, Estelle Arn-Bouldoires ${ }^{1}$, Sjoerd van Eeden ${ }^{1}$, \\ Alejandro Iglesias ${ }^{1,3}$ and Frederick Meins $\mathrm{Jr}^{1, *}$ \\ ${ }^{1}$ The Friedrich Miescher Institute for Biomedical Research, Maulbeerstrasse 66, CH-4058 Basel, Switzerland \\ (*author for correspondence; e-mail meins@fmi.ch); ${ }^{2}$ Present address: The Burnham Institute, 10901 North \\ Torrey Pines Rd., La Jolla, CA 92037, USA $;{ }^{3}$ Present address: Hoffmann-La Roche AG, Grenzacherstrasse \\ 124, CH-4070 Basel, Switzerland
}

Received 16 April 2004; accepted in revised form 12 October 2004

Key words: Ankyrin repeats, binding proteins, chitinase, $\beta$-1,3-glucanase, plant defense, sugar allocation

\begin{abstract}
The PR-like proteins, class I $\beta$-1,3-glucanase (GLU I) and chitinase (CHN I), are induced as part of a stereotypic response that can provide protection against viral, bacterial, and fungal pathogens. We have identified two Nicotiana plumbaginifolia ankyrin-repeat proteins, designated Glucanohydrolase Binding Proteins (GBP) 1 and 2, that bind GLU I and CHN I both in vitro and when expressed in yeast cells. Sense as well as antisense transformants of tobacco carrying the GBP1 gene elaborated graft-transmissible acropetally moving signals that induced the downward curling of young leaves. This phenotype was associated with reduced starch, sucrose, and fructose accumulation; the formation of necrotic lesions; and, the induction of markers for the hypersensitive response. GBP1/2 are members of a conserved Plant-specific Ankyrin- repeat (PANK) family that includes proteins implicated in carbohydrate allocation, reactive oxygen metabolism, hypersensitive cell death, rapid elicitor responses, virus pathogenesis, and auxin signaling. The similarity in phenotype of PANK transformants and transformants altered in carbohydrate metabolism leads us to propose that PANK family members are multifunctional proteins involved in linking plant defense responses and carbohydrate metabolism.
\end{abstract}

\section{Introduction}

The induction of PR-proteins and PR-like proteins is triggered stereotypically in plants by infection with fungal, bacterial, and viral pathogens, and is part of a more general response to biotic and abiotic stress (Datta and Muthukrishnan, 1999). General defense responses are regulated both locally and systemically by a complex signaling network to provide protection against pathogens (Glazebrook et al., 2003; HammondKosack and Parker, 2003). Some components of this response, such as the antifungal class I $\beta-1$, 3-glucanases (GLU I) and chitinases (CHN I), which are vacuolar PR-related proteins, act in concert to defend against a specific class of pathogens, fungi. Studies of deficient mutants suggest that GLU I may have dual defense- and counter defense-functions (Beffa et al., 1996; Iglesias and Meins, 2000a, b). Local induction of GLU I in response to virus infection actually increases the susceptibility of the plant to virus and appears to act, at least in part, by degrading callose at the cell surface important for reducing plasmodesmatal transport and virus spread (Bucher et al., 2001).

To better understand the function of GLU I in pathogenesis, we identified two Nicotiana 
plumbaginifolia ankyrin-repeat proteins, designated Glucanohydrolase Binding Proteins (GBP) 1 and 2, that interact with both GLU I and CHN I in vitro. Sense as well as antisense transformants of tobacco carrying the GBP1 gene elaborated graft-transmissible mobile signals that induced the downward curling of young leaves. This phenotype was also associated with reduced starch, fructose, and sucrose accumulation, the formation of necrotic lesions, and the induction of markers for HR. GBP $1 / 2$ are members of a conserved Plant-specific Ankyrinrepeat (PANK) family that includes members implicated in carbohydrate allocation, reactive oxygen metabolism, hypersensitive cell death, rapid elicitor responses, virus pathogenesis, and auxin signaling. We propose that PANK family members are multifunctional proteins involved in linking plant defense responses and carbohydrate metabolism.

\section{Materials and methods}

\section{Plants, plant culture, and grafting}

Unless indicated otherwise Nicotiana tabacum L. cv. Havana 425 and its transgenic derivatives were raised in a greenhouse. The sense transformant of $N$. tabacum L. cv. Xanthi nc expressing a tobacco class III $\beta-1,3$ glucanase gene was the gift of L. Friedrich (Syngenta Biotechnology, Research Triangle Park, NC, USA). The cell line S275N of Havana 425 tobacco pith tissue and its culture have been described (Felix and Meins, 1986). Where indicated, GLU I, class II $\beta$-1,3-glucanase (GLU II), and class III $\beta$-1,3-glucanase (GLU III) were induced by treating plants with either $20 \mathrm{ppm}$ of ethylene (Keefe et al., 1990) or $1.2 \mathrm{mM}$ benzothiadiazole (BTH) (Friedrich et al., 1996) and by infection of leaves with tobacco mosaic virus (Vögeli-Lange et al., 1988). Grafts were made with 70 day-old-plants with 12-13 leaves raised in a greenhouse under long-day conditions. The stems were cut between leaf 4 and leaf 5 (counting from the bottom) and the top sections were shortened so that only the apical meristem and leaves less than $3 \mathrm{~cm}$ in length remained. Reciprocal grafts were made by joining V-shaped cuts and were covered with Parafilm (American National Can, Menasha, WI, USA).

\section{Yeast two-hybrid screening}

Unless otherwise indicated standard methods for cloning and analysis of nucleic acids were used (Sambrook and Russell, 2000). The commercial Matchmaker yeast two-hybrid system (Clontech, Palo Alto, CA, USA) was used in accordance with the manufacturer's protocol. The plasmid pGLU was constructed by ligating the PCR-amplified tobacco GLU I cDNA from plasmid pSGL7 (Kunz et al., 1996) in the BamHI/PstI site of the bait vector $\mathrm{pAS} 2 \Delta \Delta$ containing a GAL4 DNAbinding domain and the Trpl gene for tryptophan synthesis. The plasmid pCHN was constructed by ligating the PCR-amplified tobacco CHN I cDNA from plasmid pSCH10 (Neuhaus et al., 1991) in the NcolI/SalI site of $\mathrm{pAS} 2 \Delta \Delta$. The prey used was a cDNA library of mature $N$. plumbaginifolia leaves in the vector pGAD10 (Clontech) containing the GAL4 transcriptional activation domain and the Leu2 gene for leucine synthesis. The reporter genes under control of the GAL4 promoter were the $\beta$-galactosidase gene and the His 3 gene for histidine synthesis. Interaction between the bait and prey proteins was judged by growth on medium without histidine, tryptophan, and leucine and the appearance of blue colonies in the $\beta$-galactosidase assay. The prey plasmids with GBP1 and GBP2 cDNA inserts are designated $\mathrm{pCY} 1$ and pCY2, respectively.

\section{Expression and purification of $G B P_{\text {his }}$}

Expression of $\mathrm{GBP}_{\text {his }}$ in Escherichia.coli strain BL21 (Novagen, Madison, WI, USA), extraction and purification by Ni-affinity chromatography were performed according to the "QIAexpressionist" handbook (Qiagen, Basel, Switzerland). The expression vector was constructed by PCR amplification of the GBP1 cDNA in pCY1 to introduce a C-terminal His tag, cutting with NdeI/ BamHI and ligating into pET-31 (Novagen).

\section{Plant transformation}

Transgenic Havana 425 tobacco plants were obtained by Agrobacterium-mediated, leaf-disc transformation (Horsch et al., 1988) with two Ti-plasmids. pSGBP1 carries a chimeric $\mathrm{GBP}_{\text {his }}$ gene derived from pCY1 regulated by a cauliflower mosaic virus 35S RNA promoter and 
transcriptional terminator (Pietrzak et al., 1986) and an hptII gene regulated by the nos promoter and $\mathrm{pA}_{\mathrm{g} 7}$ transcriptional terminator in binary vector pBIB-Hyg (Becker, 1989). pAGBP1 is the same construct with the $\mathrm{GBP}_{\text {his }}$ gene in antisense orientation. Hygromycin-resistant plants were self-pollinated and the resultant S1 generation geneotyped by PCR using primers for the left and right borders of $\mathrm{GBP}_{\text {his }}$ to identify homozygous lines monogenic for the $\mathrm{GBP}_{\text {his }}$ transgene.

\section{Assays of proteins}

Intercellular wash fluid (IWF) and extracts of leaf tissues were prepared as described earlier (Keefe et al., 1990). Extracts were clarified by centrifugation $\left(10 \mathrm{~min}, 25,000 \times \mathrm{g}, 4{ }^{\circ} \mathrm{C}\right)$ and protein concentration measured using a protein assay kit (BioRAD, Reinach, Switzerland) with bovine $\gamma$-globulin as standard. SDS-PAGE, 2D PAGE, co-immunoprecipitations and immunoblot analyses were performed by standard methods (Hames, 1998). Protein samples for 2D PAGE were prepared as described by Tsugita and Kawo (1999). Immunoblots were stained as indicated with mouse monoclonal antibodies directed against His $_{6}$ peptide (Roche Molecular Biochemicals, Indianapolis, IN, USA) and with rabbit polyclonal antibodies directed against tobacco class I-III $\beta$-1,3-glucanases (Beffa et al., 1993), tobacco CHN I (Shinshi et al., 1987), and $\mathrm{GBP}_{\text {his. }}$ Anti-GBP ${ }_{\text {his }}$ antibody was produced by Eurogentec (Herstal, Belgium) using purified $\mathrm{GBP}_{\text {his }}$ expressed in $E$. coli as the antigen. Proteins separated by SDS-PAGE were excised from the gel and nanoelectrospray ion source mass spectrometry (NanoESI-MS) was performed according to the method of Krieg et al. (1998). The mass spectra were acquired on a API 300 triple quadrupole mass spectrometer (PE Sciex, Toronto, Ontario, Canada) equipped with a NanoESI source (Protana, Odense, Denmark).

\section{Analysis of carbohydrates}

Starch was stained with $\mathrm{I}_{2}-\mathrm{KI}$ as described by Caspar et al. (1985) and quantitated by the amyloglucosidase method according to Müller et al. (1999). For gas-chromatographic analyses of soluble carbohydrates, lyophilized leaf tissue was extracted in $\mathrm{CHCl}_{3} / \mathrm{MeOH} / \mathrm{H}_{2} \mathrm{O}$, followed by liquid-liquid extraction using $\mathrm{CHCl}_{3}$ and $\mathrm{H}_{2} \mathrm{O}$.
The polar and apolar fractions were separated and dried under vacuum. The polar fraction was subjected to methoximation with $2 \%$ methoxyamine $\cdot \mathrm{HCL}$ in Pyridine (MOX reagent, Pierce Biotechnologies, Greifensee, Switzerland) at $90{ }^{\circ} \mathrm{C}$ for $90 \mathrm{~min}$, followed by evaporation to dryness and then silylation with $N$-methyl- $N$-trimethylsilyl trifluoacetamide (BSTFA, Pierce Biotechnologies) at $90{ }^{\circ} \mathrm{C}$ for $20 \mathrm{~min}$, followed by evaporation to dryness. GC/MS analysis was performed using the following conditions: injector at $280{ }^{\circ} \mathrm{C}$, with helium as carrier gas at a gas flow of $1.2 \mathrm{ml} / \mathrm{min}$, split: $1: 10$; oven $50{ }^{\circ} \mathrm{C} / 0 \mathrm{~min}-10^{\circ} \mathrm{C} / \mathrm{min}-$ $100{ }^{\circ} \mathrm{C} / 0 \min -4{ }^{\circ} \mathrm{C} / \min -200{ }^{\circ} \mathrm{C} / 0 \min -10{ }^{\circ} \mathrm{C} /$ $\min -320^{\circ} \mathrm{C} / 5 \mathrm{~min}$, with a transferline temperature of $300{ }^{\circ} \mathrm{C}$; MS with a mass range $50-650 \mathrm{amu}$, $0.5 \mathrm{~s}$ scan time, ion source temperature of $220^{\circ} \mathrm{C}$, electron energy of $70 \mathrm{eV}$. The apolar fraction was subjected to methanolysis with $3 \mathrm{~N} \mathrm{HCl} / \mathrm{MeOH}$ (Supelco, Fulka, Buchs, Switzerland) at $80{ }^{\circ} \mathrm{C}$ for $4 \mathrm{~h}$, followed by evaporation to dryness and then silylation with BSTFA at $90{ }^{\circ} \mathrm{C}$ for $20 \mathrm{~min}$, followed by evaporation to dryness. GC/MS analysis was performed using the following conditions: injector at $280{ }^{\circ} \mathrm{C}$, with helium as carrier gas at a gas flow of $1.2 \mathrm{ml} / \mathrm{min}$, split: $1: 10$; oven $100{ }^{\circ} \mathrm{C} /$ $0 \min -14{ }^{\circ} \mathrm{C} / \min -230{ }^{\circ} \mathrm{C} / 0 \min -5{ }^{\circ} \mathrm{C} / \min -$ $280{ }^{\circ} \mathrm{C} / 0 \min -20{ }^{\circ} \mathrm{C} / \min -320^{\circ} \mathrm{C} / 6$ min, with a transferline temperature of $300{ }^{\circ} \mathrm{C}$; MS with a mass range 50-650 amu, $0.5 \mathrm{~s}$ scan time, ion source temperature of $220^{\circ} \mathrm{C}$, electron energy of $70 \mathrm{eV}$. Sugar content is expressed in arbitrary units relative to an internal standard.

\section{Results}

\section{Identification of GLU I/CHN I binding proteins}

Yeast two hybrid screens were used to identify proteins that interact with two vacuolar glucanohydrolases. cDNAs encoding tobacco CHN I and GLU I were used to screen a $N$. plumbaginifolia cDNA library. As judged by growth and blue coloration on the SD/Gal/Raf/-his/-Leu/-Trp/ $\mathrm{Ura} / \mathrm{X}$-gal assay medium, proteins encoded by eight cDNAs interacted with GLU I and seven interacted with CHN I. Sequence analysis identified two clones from the CHN I screen representing the same mRNA, which we designated Glucanohydrolase Binding Protein 1 (GBP1). One 
clone in the GLU I screen was very similar in sequence to GBP1 and was designated GBP2. We confirmed that GBP1 and GBP2 interacted with both CHN I and GLU I in yeast two-hybrid growth tests and by the formation of blue colonies in $\beta$-galactosidase assays (data not shown).

To facilitate biochemical studies, a recombinant form of GBP I carrying a C-terminal tag of six histidine residues $\left(\mathrm{GBP}_{\text {his }}\right)$ was expressed in E. coli and purified by metal-affinity chromatography. SDS-PAGE gels of the proteins purified from empty-vector and $\mathrm{GBP}_{\text {his }}$ transformed $E$. coli were stained with Coomassie blue and immunoblotted with antibodies directed against the His tag (Figure 1). Three abundant polypeptides were

\section{(A)}
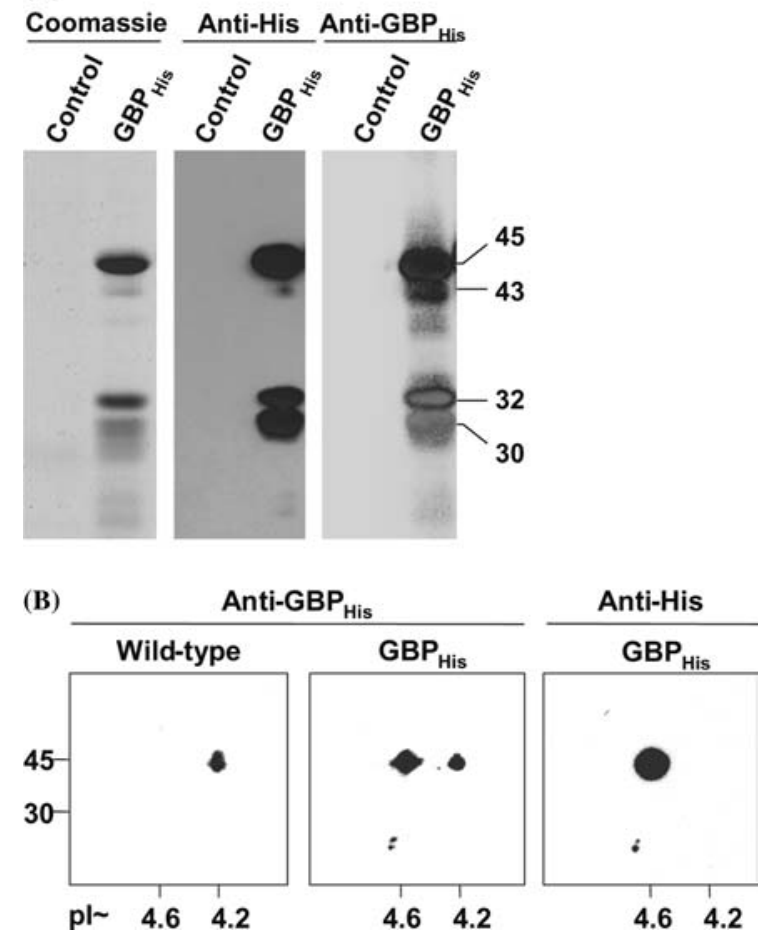

Figure 1. Immunoblot analyses of $\mathrm{GBP}_{\text {his }}$ expressed in E. coli and in tobacco. (A) SDS-PAGE of proteins purified by metalaffinity chromatography from empty vector (control) and $\mathrm{GBP}_{\text {his }}$ transformed $E$. coli. The gels were either stained with Comassie blue (left panel) or immunoblotted and the blots stained as indicated with anti-his or anti-GBP $\mathrm{Gis}_{\text {his }}$ antibodies (middle and right panels). Sizes in $\mathrm{kDa}$ of the major polypeptides detected are indicated on the right. (B) 2D-PAGE of protein extracts prepared from leaves of wild-type tobacco and a sense $\mathrm{GBP}_{\text {his }}$ transformant. Immunoblots were stained as indicated with anti-GBP ${ }_{\text {his }}$ and anti-His antibodies. The sizes in $\mathrm{kDa}$ of the major polypeptides detected are indicated on the left; the isoelectric points are indicated at the bottom. recognized by the anti-His antibodies that were present in the $\mathrm{GBP}_{\text {his }}$ transformed cells but not in control cells. None of the immunoreactive proteins corresponded in size to the deduced $38.2 \mathrm{kDa}$ $\mathrm{GBP}_{\text {his }}$ polypeptide. Mass spectrometry showed that the immunoreactive protein at the $45 \mathrm{kDa}$ position in gels corresponds to full-length, $38.2 \mathrm{kDa} \mathrm{GBP}_{\text {his. }}$ Thus, as reported for other acidic proteins (Kaufmann et al., 1984), $\mathrm{GBP}_{\text {his }}$ (predicted pI 4.54) runs anomalously in SDS-PAGE. The protein at the $45 \mathrm{kDa}$ position was used to elicit antibodies in rabbits. The anti-GBP ${ }_{\text {his }}$ antibody obtained and anti-His antibody recognized $45,43,32$, and $30 \mathrm{kDa}$ proteins (Figure 1A). Polypeptides smaller than the predicted full-length molecules could result from N-terminal degradation or internal translational initiation. Specificity of the anti- $\mathrm{GBP}_{\text {his }}$ antibody was confirmed by immunoblot analyses of 2D-PAGE-separated proteins prepared from wild-type and $\mathrm{GBP}_{\text {his }}{ }^{-}$ transformed tobacco (Figure 1B). Tobacco extracts gave a single $45 \mathrm{kDa}$ immunoreactive protein of $\mathrm{p} I 4.2$, close to the predicted $\mathrm{p} I 4.3$ for GBP I.

We used far-western assays to detect possible biochemical interaction of GBP I with GLU I and CHN I. Extracts prepared from tobacco leaves were supplemented with increasing concentrations of GLU I and CHN I and then fractionated by SDS-PAGE. The separated proteins were transferred to a membrane, which was incubated in $\mathrm{GBP}_{\text {his }}$ and then immunoblotted with anti $\mathrm{GBP}_{\text {his }}$ antibody. Figure 2 shows that although samples of unsupplemented extracts contained CHN I and GLU I binding of $\mathrm{GBP}_{\text {his }}$

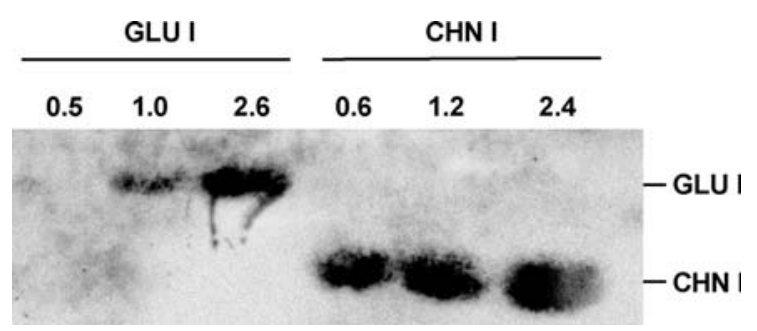

Figure 2. Biochemical confirmation that GBP interacts with both GLU I and CHN I. Tobacco extracts ( $5 \mu \mathrm{l} / \mathrm{lane})$ supplemented with the amount (ng) of GLU I and CHN I indicated were fractionated by SDS-PAGE and transferred to a membrane. The membranes were incubated in $0.1 \mu \mathrm{M} \mathrm{GBP}_{\text {his }}$, washed and then immuno-stained with anti-GBP $\mathrm{Gis}_{\text {his }}$ antibodies. The positions of GLU I and CHN I are indicated on the right. 
to CHN I and GLU I was only detected in the supplemented extracts. In related studies not shown, test proteins spotted on a membrane were incubated with $\mathrm{GBP}_{\text {his }}$. $\mathrm{GBP}_{\text {his }}$ binding was detected with GLU I and CHN I, but not with various structurally unrelated acidic and basic hydrolases including laminarinase $(\mathrm{p} I=4.2)$, cellulase $(\mathrm{p} I=4.8), \beta$-glucuronidase $(\mathrm{p} I=5.2)$, and lysozyme $(\mathrm{p} I=9.2)$. Although interactions were detectable by co-immunoprecipitation using anti$\mathrm{GBP}_{\text {his }}$ antibodies and detection of GLU I with anti-GLU I antibodies, these results could not be obtained consistently (data not shown). Thus, our findings confirm biochemically that GBP specifically binds both CHN I and GLU I in vitro, but not in vivo.

\section{GBP1 and GBP2 are members of a plant specific ankyrin-repeat family}

Analysis of the deduced, 348 amino acid long GBP1 polypeptide with Pfam software (Bateman et al., 2002) revealed two regions with significant homology to the ankyrin-repeat domain $(E<$ 0.05 ) and a third, apparently incomplete C-terminal ankyrin-repeat domain $(E=0.14)$. Ankyrinrepeat domains are typically involved in proteinprotein interactions (Andrade et al., 2001). The deduced GBP2 polypeptide, although $84 \%$ identical in amino-acid sequence to GBP1, is 203 amino-acids in length and lacks the ankyrin repeats. We searched the Protein Database with BLASTP software (Altschul, et al., 1997) using the deduced, N-terminal 1-210 amino-acid sequence of GBP1 and GBP2 upstream of the ankyrin-repeat region. Only plant proteins with C-terminal ankyrin repeats showed significant sequence identity $(E<6 \mathrm{e}-21)$. Moreover, analyses using Motif Search software (http://www.genome.ad.jp) showed that all full-length proteins in this group have at least one signature for the glycosyl hydrolase superfamily (Figure 3a). In most cases, a family 6 signature was close to the $\mathrm{N}$-terminal end of the protein. Based on proposed phyletic relations and the comparison of domain structures summarized in Figure 3 we propose that these proteins comprise a conserved, PANK family with members in cereals, eudicots, and the green alga Chlamydomonas rheinhardii. Comparisions of complete amino acid sequences suggest that GBP1 is an ortholog $96.3 \%$ identical in sequence to the
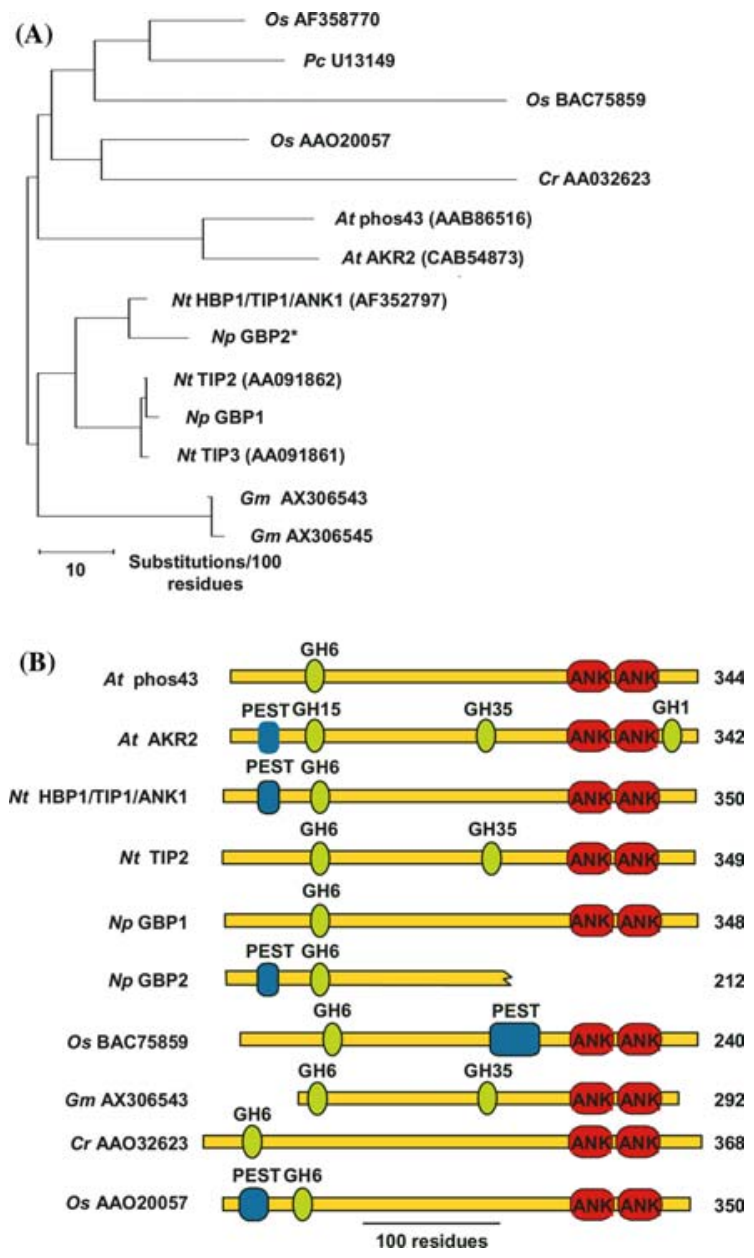

Figure 3. Comparison of the amino-acid sequences and domain structures of PANK family proteins. (A) An un-rooted phylogenetic tree of representative PANKs showing Kimura-corrected distances expressed in substitutions per 100 residues. The tree was generated using SeqWeb 1.2 GrowTree software from the polypeptide sequences indicated. With exception of GBP2, the polypeptides compared were full length. The examples shown are the Eudicots tobacco ( $N$. tabacum, Nt), N. plumbaginifolia (Np), Arabidopsis thaliana (At), and soybean (Glycine max, Gm); the cereals Pennisetum ciliare $(P c)$ and rice (Oryza sativa, Os); and the Chlorophyta Chlamydomonas reinhardtii $(\mathrm{Cr})$. (B) Comparison of sequence features of representative PANKs with the highly conserved ankyrin-repeat domains aligned. ANK, ankyrin-repeat domain; GH, glucosyl hydrolase family signatures; PEST, PEST regions. The lengths of the polypeptides are indicated on the right.

tobacco protein TIP2 (AA091862). GBP2 (?), which lacks the ankyrin-repeat domain, is $98.2 \%$ identical in sequence to the tobacco protein AF352797 independently reported as HBP1, TIP1, and ANK1 (Fridborg et al., 2003; Kuhlmann et al., 2003). Therefore, we believe that GBP2 
identified in the yeast two-hybrid screen is an incomplete cDNA clone representing a full-length ortholog of tobacco HBP1/TIP1/ANK1. Using PESTfind software (http://www.at.embnet.org/ embnet/tools/bio/) we could identify a high-scoring PEST region (score +10.3 ) in GBP2, but not in GBP1 (Figure 3B). High-scoring PEST regions were also identified at conserved positions in PANK members of tobacco (AF352797, score $+17.3)$, rice (AAO20057, score + 11.5; BAC75859, score +8.1 ; AF358770, score +8.3$)$, and wheat (AF475105, score +5.5 ). A PEST region has also been reported for Arabidopsis AKR2 (CAB54873) (Yan et al., 2002). PEST sequences have been implicated in the targeting of proteins for degradation in the proteosome (Rechsteiner and Rogers, 1996).

\section{GBP expression is developmentally regulated}

Immunoblot analysis of extracts prepared from organs of mature tobacco plants showed that the 45-kDa GBP antigen detected with anti-GBP ${ }_{\text {his }}$ antibody is abundant in the stem and leaves (Figure 4A). Lower amounts were detected in flowers, and only trace amounts were detected in roots. Lower concentrations of a ca. $43-\mathrm{kDa}$ immunoreactive protein, which is likely to be a truncated form of GBP, were also detected. ELISA quantitation showed that GBP content decreases in leaves from the bottom to the top of the plant (Figure 4B).

To find out if GBP is secreted into the extracellular space, we compared the GBP content of total extracts and IWF prepared from the same leaf. As a positive control, we used extracts prepared from leaves of tobacco transformed with class III $\beta-1,3$-glucanase (GLU III), which is secreted (Payne et al., 1990). Although GLU III was detected in both IWF and total extracts, GBP was only detected in total extracts indicating that GBP is not secreted into the extracellular space (Figure 4C). These results were confirmed for a suspension culture of tobacco: GBP antigen was detected in cell extracts, but not in the culture medium (Figure 4D).

The PR-2/PR-2 like proteins GLU I, GLU II, and GLU III are induced by infection with TMV and treatment with BTH, which induce systemic acquired resistance (Friedrich et al., 1996; Ryals et al., 1992); whereas, GLU I, but not GLU II and
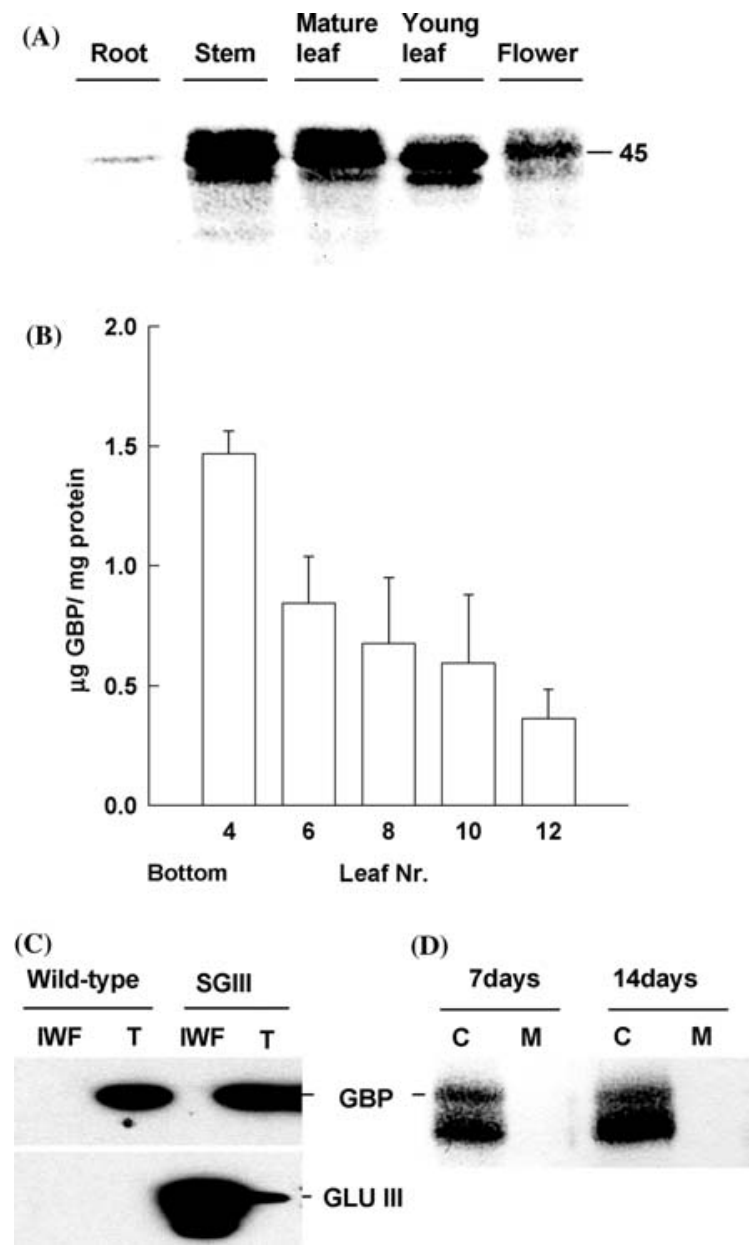

Figure 4. The organ distribution and cellular localization of GBP in tobacco. (A) Representative immunoblot analysis of extracts prepared from organs of a 3-month-old Havana 425 tobacco plant. The size in $\mathrm{kDa}$ of full-length GBP is indicated. (B) ELISA assay of GBP in leaves of 70-day-old Havana 425 tobacco plants. Data are expressed as average $\mu \mathrm{g} \mathrm{GBP} / \mathrm{mg}$ soluble protein \pm SEM for three replicate plants. Leaves are numbered from the bottom of the plant. (C) Immunoblot analysis of GBP and GLU III in intercellular wash fluid (IWF) and tissue extracts $(\mathrm{T})$ prepared from leaves of wild type and GLU III-transformed Xanthi nc tobacco plants. (D) Immunoblot analysis of extracts prepared from S275N Havana 425 tobacco cells $(\mathrm{C})$ and medium $(\mathrm{M})$ of suspensions 7 and 14 days after subculture. For Immunoblot analyses (a, c, and d) equal amounts of protein were loaded in each lane.

GLU III are induced by ethylene treatment (Leubner-Metzger and Meins, 1999). Immunoblot analyses of leaf extracts with antibodies directed against $\mathrm{GBP}_{\text {his }}$ and the three $\beta-1,3$-glucanase isoforms showed that GBP content was not increased by these treatments (data not shown). These results suggest that no appreciable GBP induction 
is associated with the pathogenesis response of tobacco.

$G B P_{\text {his }}$ transformants show a curled-leaf phenotype and form HR-like lesions

We transformed tobacco with constructs carrying chimeric $\mathrm{GBP}_{\text {his }}$ genes in sense and antisense orientation regulated by the cauliflower mosaic virus 35S RNA promoter as well as a selectable hygromycin-resistance marker. Six of 46 independent sense transformants and 11 of 28 antisense transformants showed extreme downward curling of upper leaves. Primary, hygromycin-resistant transformants were selfed pollinated and homozygous lines monogenic for $\mathrm{GBP}_{\text {his }}$ in the resultant S1 generation were identified by PCR genotyping. Two lines each of sense transformants (TSGBP1.1 and TSGBP1.69) and antisense transformants (TAGBP1.14 and TAGBP1.52) showing a strong curled-leaf phenotype were studied in detail. Immunoblotting confirmed high-level expression of $\mathrm{GBP}_{\text {his }}$ in the sense lines (Figures $1 \mathrm{~B}$ and $6 \mathrm{D}$ ). Unexpectedly, the expression of GBP and GBP mRNA in antisense lines was highly variable and was not consistently lower than that of wild type (data not shown).

Severity of the curled-leaf phenotype varied from plant-to-plant and ranged from mild bending of the leaf edge to pronounced curling to give cupshaped leaves (Figure 5A-C). This abnormality usually occurred in 1-2 month-old plants at the 8-10 leaf stage. No curling of previously formed, fully expanded leaves was observed and curled leaves did not revert to normal. Curling was most pronounced in leaves near the top of the plant.
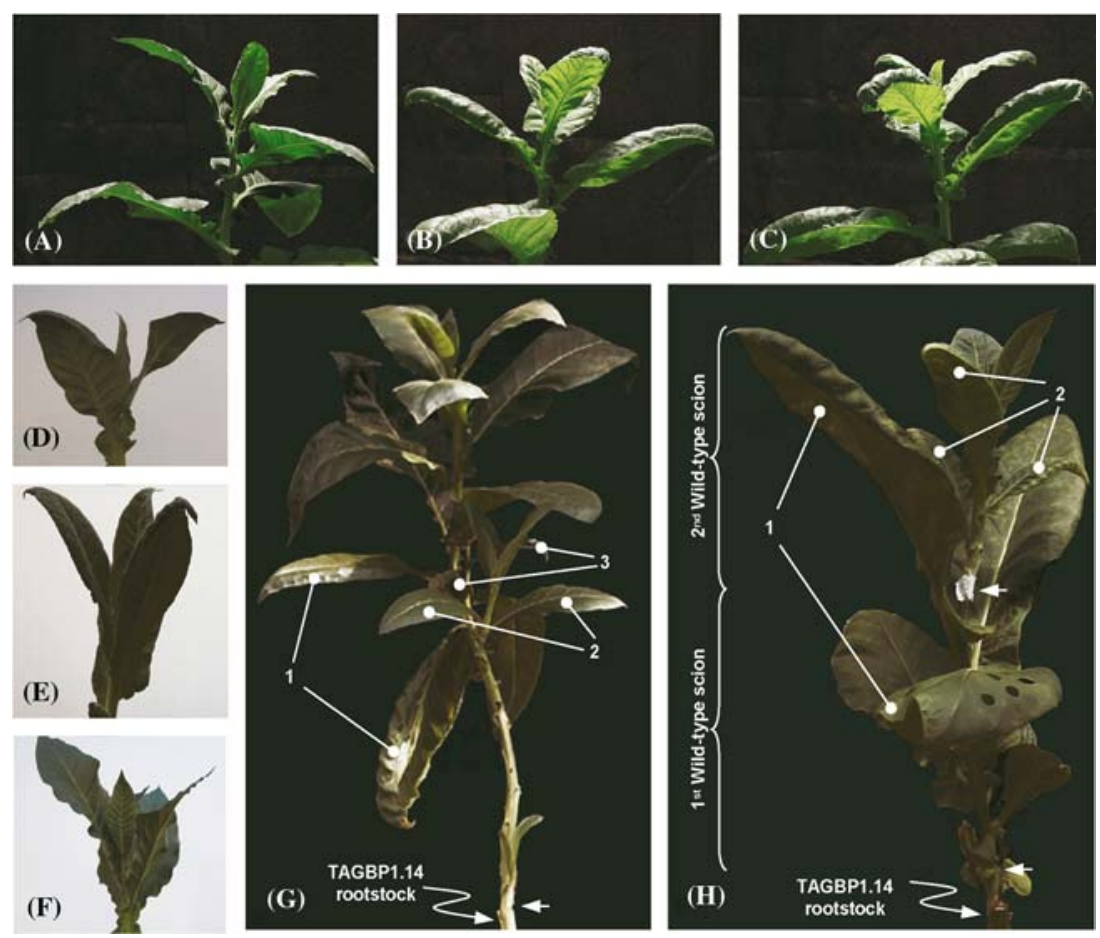

(F)

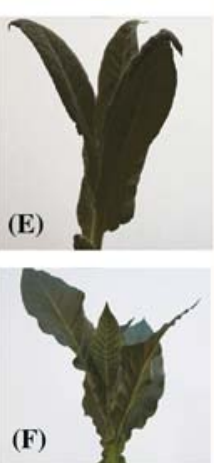

(G)

Figure 5. Representative plants transformed with $\mathrm{GBP}_{\text {his }}$ sense and antisense constructs. Two-month-old wild type (A), sense TSGBP1.69 (B), and antisense TAGBP1.14 (C) Havana 425 plants grown in the greenhouse. The characteristic downward curling of young leaves is visible in both sense (B) and antisense (C) transformants, but is absent in un-transformed control plants (A). Photographs taken 18 days after grafting showing that wild-type scions grafted onto TSGBP1.69 (D), TAGBP1.14 (E), but not wildtype (F) rootstocks show downward curling of newly formed leaves. $(\mathrm{G})$ Experiment showing that acropetally moving factors induce curling of leaves on newly formed lateral shoots. 1, leaves on the main stem showing curling; 2, normal leaves on the lateral shoot formed below curled leaves on the main stem; 3 , curled leaves on the lateral shoot formed between curled leaves on the main stem. The arrow indicates where the wild-type scion was grafted on the TAGBP1.14 rootstock. $(\mathrm{H})$ Successive grafting of a second wild-type scion (top) onto a wild-type scion with curled leaves (middle) that had been grafted earlier on a TAGB1.14 root stock (bottom). Arrows indicate the graft sites. Note that curled leaves ( 1 and 2$)$ form on the first and second grafts, respectively. 

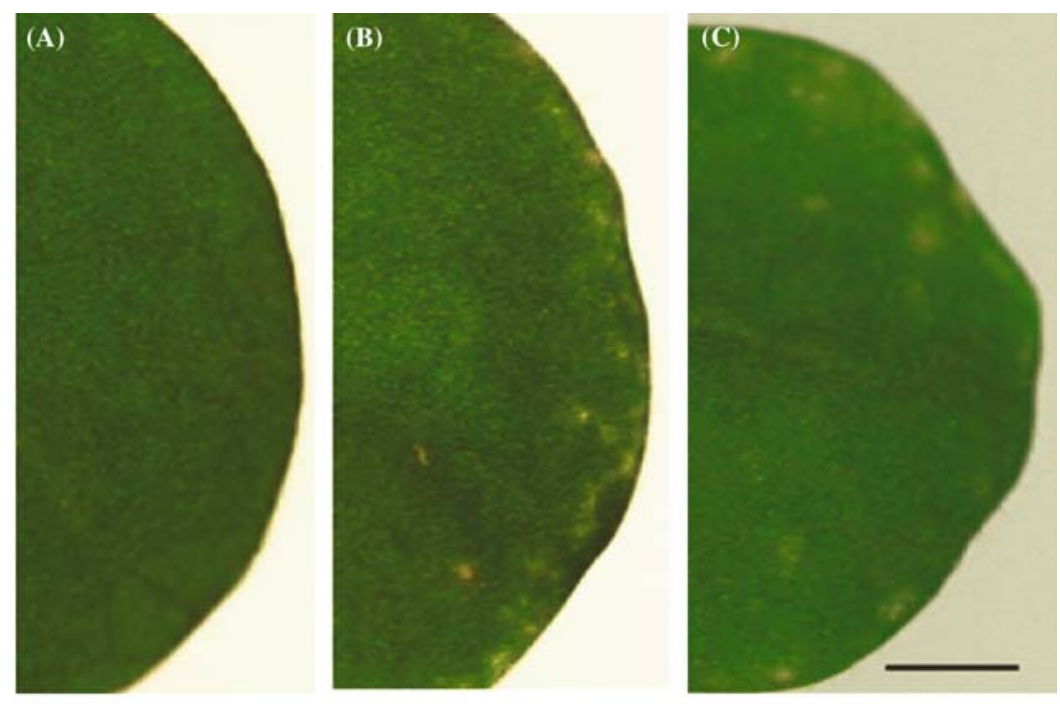

(D) Wild type TSGBP1.1 TSGBP1.69

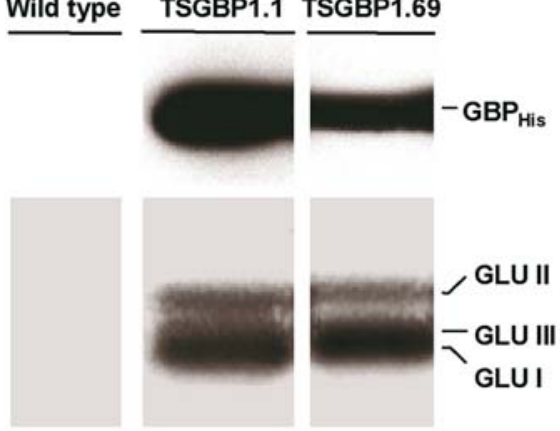

Figure 6. Transgenic $\mathrm{GBP}_{\text {his }}$ plants spontaneously form necrotic lesions in association with the local induction of HR markers. Representative leaves of axenically grown wild-type (A), sense TSGBP1.69 (B) and antisense TAGBP1.14 (C) plantlets. Necrotic lesions form along the margin of the sense (B) and antisense (C) leaves. Bar, $2 \mathrm{~mm}$. (D) Immunoblot analysis of extracts prepared from leaves of axenically grown wild-type wild type and sense (TSGBP1.1 and TSCGBP1.69) plantlets. The upper and lower blots were stained with antibodies recognizing the tag and GLU I-III, respectively. The positions of GBP ${ }_{\text {his }}$, GLU I, GLU II, and GLU III on the blots are indicated on the right. Equal amounts of protein were loaded into each lane.

Interestingly, lower leaves that were not curled often formed necrotic lesions along their edges. These lesions, which are first apparent as discrete chlorotic spots, also formed on leaves of axenically grown plants indicating that they did not result from microbial infection (Figure 6A-C). Formation of necrotic lesions as part of the HR to microbial infection is associated with the local induction of PR and PR-like proteins including GLU I, GLU II and GLU III (Ryals et al., 1996). Immunoblot analyses confirmed that these $\beta$-1,3-glucanases were also induced in leaves with lesions on sense transformants expressing high levels of $\mathrm{GBP}_{\text {his }}$ (Figure 6D). Thus, the $\mathrm{GBP}_{\text {his }}$ transformants spontaneously form HR-like necrotic lesions.

\section{Leaf curling is induced by systemic signals}

To find out if leaf curling is a systemic effect, we made informative grafts between wild type plants and $\mathrm{GBP}_{\text {his }}$ transformants. Pairs of 70 day-old plants with $12-13$ leaves were grafted reciprocally. At least two plants of each genotype were tested. Scions were scored for leaf curling 18 days after grafting when the scions had 5-6 newly formed leaves. The results expressed as the average number of curled leaves per scion are summarized in Table 1.

Curling in the five lowest leaves of wild-type scions was observed 18 days after grafting onto the sense and antisense rootstocks tested (Figure 5D, E). 
Table 1. Incidence of curled leaves in reciprocal grafts.

\begin{tabular}{lll}
\hline Rootstock & Scion & Curled leaves/scion \\
\hline TSGBP1.69 & TSGBP1.69 & $3(2)$ \\
TSGBP1.69 & Wild type & $2(4)$ \\
Wild type & TSGBP1.69 & $2(4)$ \\
TSGBP1.1 & TSGBP1.1 & $1(1)$ \\
TSGBP1.1 & Wild type & $1(3)$ \\
Wild type & TSGBP1.1 & $1(3)$ \\
TAGBP1.14 & TAGBP1.14 & $6(2)$ \\
TAGBP1.14 & Wild type & $6(6)$ \\
Wild type & TAGBP1.14 & $3(6)$ \\
TAGBP1.52 & TAGBP1.52 & $5(2)$ \\
TAGBP1.52 & Wild type & $2(2)$ \\
Wild type & TAGBP1.52 & $1(2)$ \\
Wild type & Wild type & $0(3)$ \\
\hline
\end{tabular}

Data are expressed as the average number of curled leaves/plant for the number of plants indicated in parenthesis scored 28 days after grafting.

No curling was observed in grafts of wild type on wild type (Figure 5F) even after 60 days when the experiment was terminated. Similar results for more than 50 wild-type grafts were obtained in earlier experiments. In decreasing order, the severity of the curled-leaf phenotype for the rootstocks used was TAGBP1.14 > TAGBP1.52 > TSGBP1.69 > TSGBP1.1. When scions had 6-8 fully-expanded leaves 28 days after grafting, the wild-type scions showed curling of 5-6 leaves if the root stock was TAGBP1.14 and of 1-3 leaves if the root stock was TAGBP1.52, TSGBP1.69, or TSGBP1.1. $\mathrm{GBP}_{\text {his }}$ transformed scions grafted onto wild-type rootstocks displayed no curling or much milder curling than their wild-type counterparts 18 days after grafting. Twenty-eight days after grafting, only $2-3$ lower leaves (TAGBP1.14 and TAGBP1.52) or 1-2 lower leaves (TSGBP1.69 and TSGBP1.1) were affected, and the curling was much less pronounced than in corresponding reciprocal grafts and control grafts. These results show that graft transmissible factors are responsible for curling of newly formed scion leaves; that this effect depends on the genotype of the rootstock, but not on the genotype of the scion; and, that sense and antisense $\mathrm{GBP}_{\text {his }}$ rootstocks have similar effects.

We also assayed for the persistence of induced leaf curling. Wild-type scions were grafted onto transgenic rootstock. The scions, which showed pronounced leaf curling, were then re-grafted onto wild-type rootstock. After 27 days, no curling was observed in any of the six re-grafted scions. Moreover, the curled leaf phenotype was not transmitted through seed of wild-type scions showing this phenotype. Taken together, this implies that leaf curling is a physiological response either inhibited by factors produced by wild type or induced by factors produced by the transgenics that move acropetally from the rootstock to the scion.

Growth of lateral shoots is activated by decapitation. Lateral shoots of decapitated transgenic plants as well as decapitated wild-type scions grafted onto transgenic rootstock consistently showed leaf curling. In contrast, no leaf curling was observed on lateral shoots arising from six wild-type rootstocks with transgenic scions. Thus, factors influencing leaf curling do not appear to move in the basepetal direction. To distinguish between inhibitory and inductive factors, we grafted wild type onto transgenic rootstock and, after 18 days, removed all leaves from the rootstock and all leaves longer than $1 \mathrm{~cm}$ from the scion. Forty days later, 11-12 leaves had formed from the apical meristem of scion and 2-3 lowest leaves were curled. Leaves on the lateral shoot that developed above the curled leaves were also curled (Figure 5G). In contrast, leaves on the lateral shoot that formed below the curled leaves were normal. These results support the hypothesis that mature transgenic leaves and mature leaves of wild type grafted onto transgenic rootstock produce a factor that induces curling of younger target leaves. This hypothesis is also consistent with results of experiments in which a second wild-type scion was grafted onto a wild-type scion with mature curled leaves that had been grafted on transgenic rootstock. The second scions in the five grafts made showed the curled-leaf phenotype (Figure 5H) suggesting that the putative inducing factor can travel through wild-type stem or that wild-type stem segments with induced curled leaves produce this factor.

\section{$G B P_{\text {his }}$ transformants show alterations in carbohydrate metabolism}

Reports that a curled-leaf phenotype can arise in transformants altered in carbohydrate metabolism (Sonnewald et al., 1991; Sheveleva et al., 2000) prompted us to compare the starch and soluble sugar contents of wild type and $\mathrm{GBP}_{\text {his }}$ 
transformants. Figure 7A, B shows by $\mathrm{I}_{2}-\mathrm{KI}$ staining that the starch content of transgenic curled leaves was considerably reduced relative to wild-type leaves at the same developmental stage. This effect was particularly pronounced in the $2-3 \mathrm{~cm}$ wide, curled region at the edge of the leaves. Starch content was measured quantitatively in samples of leaf lamella taken from near the midvein to minimize possible effects of leaf curling on light exposure. Figure $7 \mathrm{C}$ shows that starch content decreases in leaves from the bottom to the top of the plant and that this decrease is more pronounced in sense and antisense $\mathrm{GBP}_{\text {his }}$ transformants than in wild type. We also measured the sucrose, fructose, and glucose content of pooled leaves from wild-type plants and antisense line TAGBP1.14, which showed pronounced curling of upper leaves (Figure 5C). Relative to wild type, this line showed small, but significant reductions in sucrose content $(39 \%$, $T$-test of means, $P<0.01)$ and fructose content $(12 \%, T$-test of means, $P<0.05)$ (Figure 7D). Glucose content did not differ. Taken together these results show that starch, sucrose, and fructose accumulation are reduced in transgenic curled-leaf plants relative to wild type.

\section{Discussion}

GBP and TIP orthologs interact with vacuolar glucanohydrolases and a viral movement protein

The $N$. plumbaginifolia glucanohydrolase-binding proteins we identified in yeast two hybrid screens are orthologs of the tobacco TIP proteins. Comparisons of amino-acid sequences and domain structures indicate that GBP2 is the ortholog most closely related to HBP1/ANK1/TIP1, and that GBP1 is the ortholog most closely related to TIP2. Recently, Fridborg et al. (2003) showed that TIP interacts with GLU I and binds the potyvirus X (PVX) triple block protein TGB12K required for cell-to-cell movement of PVX. Our studies show that TIP/GBP proteins can also bind CHN I, which is coordinately induced with GLU I by ethylene treatment and in association with HR (Leubner-Metzger and Meins, 1999). We also showed that GBP binding to GLU I and CHN I does not depend the ankyrin-repeat domain. Although the GBP2 cDNA appears to be truncated,
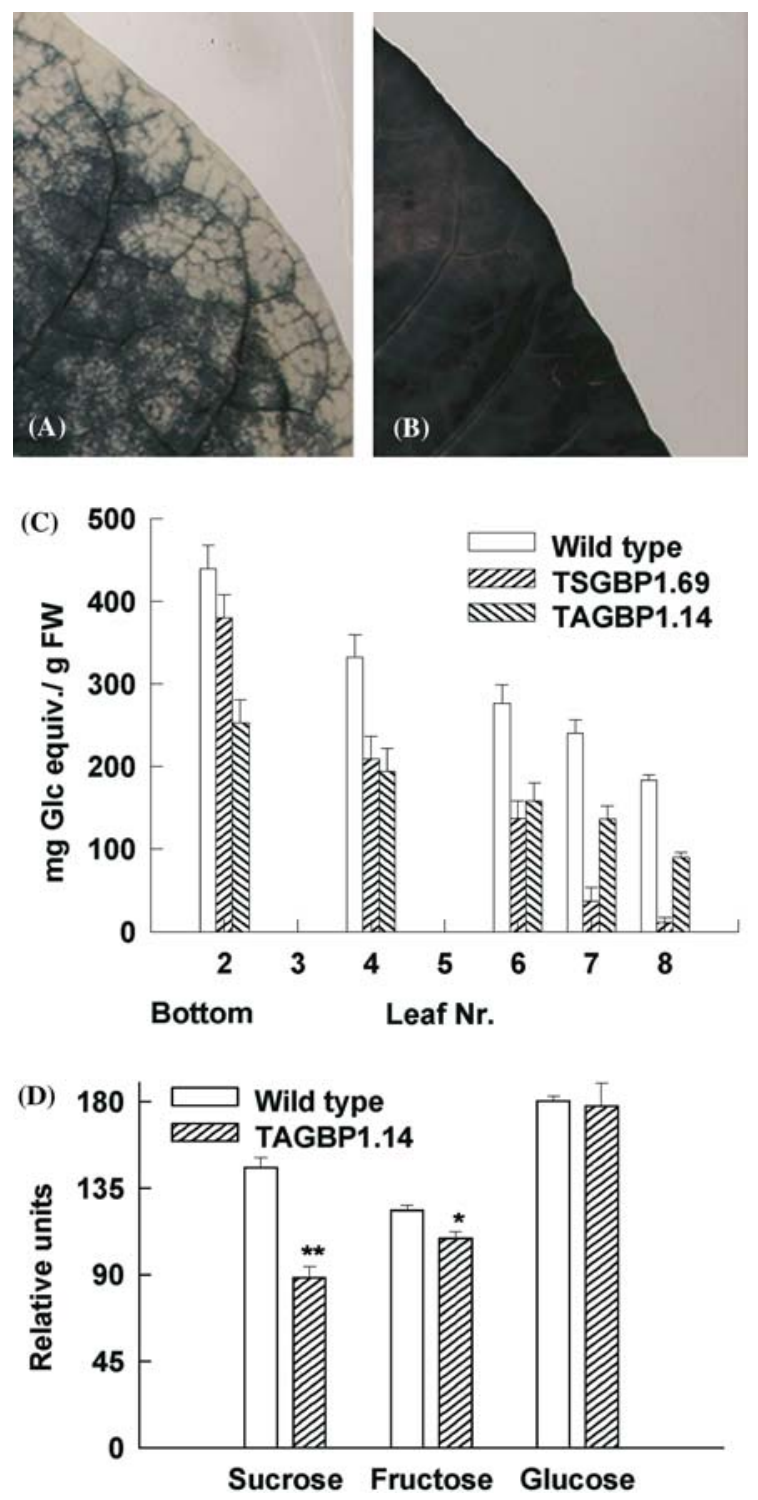

Figure 7. Transgenic $\mathrm{GBP}_{\text {his }}$ plants show alterations in carbohydrate metabolism. The distribution of starch (blue coloration) at the margin of TAGBP1.12 leaves (A) and wild-type leaves (B) stained with $\mathrm{I}_{2}-\mathrm{KI}$. (C) Quantitative measurement of starch in leaves of wild-type, sense (TSGBP1.69) and antisense (TAGBP1.14) plants. The data are expressed as average starch content in $\mathrm{mg}$ glucose equivalents per g. F.W. \pm SEM for three replicate plants. Leaves are numbered counting from the bottom of plants with nine expanded leaves. (D) The sucrose, fructose, and glucose content of leaves from wild type and antisense (TAGBP1.14) plants. The sugars were measured by gaschromatography and contents expressed in average units relative to an internal standard \pm SEM for three replicate plants. In each case leaf 12 counting from the bottom of plants with 15 expanded leaves was sampled. 
the protein encoded by this cDNA, which lacks the ankyrin-repeat domain, was still active in binding.

Although membrane-based assays biochemically confirmed the yeast two-hybrid results, our co-immunoprecipitation experiments did not show that this binding consistently occurs in vivo as reported for GLU I and TIP by Fridborg et al. (2003). One possible explanation for the discrepancy between the TIP and GBP results is that the interactions are mediated by factors not present in the plant extracts we tested. Another possibility is that other proteins, for example, the secreted isoforms of chitinase and $\beta$-1,3-glucanase are the physiologically relevant binding partners. These are attractive candidates because they are ca. 50\% identical in amino-acid sequence and cross-react immunologically with their respective class I isoforms and are induced systemically in virus infection (Ward et al., 1991).

GBP1/2 and the TIP orthologues are predicted cytoplasmic proteins. Fridborg et al. (2003) found that a TIP-GFP fusion protein is distributed uniformly in the cytoplasm of uninfected cells and is targeted to peripheral cytoplasmic sites, presumed to contain virus, following PVX infection. We confirmed the cytoplasmic localization of a GBP1-GFP fusion for uninfected cells (Wirdnam, unpublished). Thus, GBP/TIP and the TGB12K binding partner co-localize in the same cellular compartment. On the other hand, the GLU I and CHN I binding partners are vacuolar proteins (Iglesias and Meins, 2000a, b). Paradoxically, GLU I has been shown to have extracellular functions in seed germination and regulating callose (Bucher et al., 2001; LeubnerMetzger, 2003) suggestive of dual targeting to the vacuole and extracellular compartments. Although vacuolar GLU I and CHN I can be secreted by cultured tobacco cells (Kunze et al., 1998), we did not detect secretion of GBP1 tested under the same conditions. Thus, at present, there is no evidence for the co-localization of GBP1 with GLU I and CHN I and the functional relevance of the interactions detected in vitro is still unclear.

\section{Sense- and antisense transformants show a similar phenotype}

Numerous independent sense and antisense GBP transformants showed a similar abnormal phenotype, which, in the case of the sense transformants, was correlated with GBP over-expression. The antisense results are more difficult to interpret. We were unable to find consistently reduced expression of GBP or GBP mRNA in the antisense transformants relative to wild-type plants. This has been reported for other plant antisense transformants; the explanation is unknown (Bourque, 1995). Interestingly, expression of antisense or sense RNA of a gene encoding an ankyrin-repeat protein unrelated to GBP in transgenic Arabidopsis results in the same abnormalities in chloroplast differentiation (Zhang et al., 1992). If one assumes that GBP/TIP expression is reduced in critical target cells by antisense, then our results suggest that an optimum GBP/TIP concentration is required for normal function. Whatever the role of GBP/TIP may be in virus infection, our expression studies show that GBP/TIP concentration, although developmentally regulated, is not induced in response to virus infection or as part of the plant-defense response to microbial pathogens.

\section{GBP1/2 are members of the PANKS family implicated in pathogen defense responses and carbohydrate metabolism}

Our database searches lead us to conclude that GBP $1 / 2$ are members of a conserved, plant-specific ankyrin-repeat family. In addition to GBP several other PANKs or their binding partners have been implicated in plant-defense responses. Tobacco HBP1/ANK1/TIP1 interacts with the bZIP transcription factor BZI-1 blocking the binding of this transcription factor to DNA. Studies with dominant negative constructs suggest that BZI-1 is a negative regulator of $\mathrm{HR}$ and a positive regulator of auxin responses of roots (Kuhlmann et al., 2003). The Arabidopsis PANK AKR2 interacts with both ascorbate peroxidase 3 (APX3), which is believed to be an $\mathrm{H}_{2} \mathrm{O}_{2}$ scavenger, and the 14-3-3 protein GF $14 \lambda$, which also interacts with APX3. This, together with the finding that antisense AKR2 plants show elevated $\mathrm{H}_{2} \mathrm{O}_{2}$ levels and spontaneous HR-like lesions, led Yan et al. (2002) to propose that AKR2 acting via APX3 has a role in regulating oxidative metabolism associated with HR. Finally, the Arabidopsis PANK phos43 is rapidly phosphorylated in response to treatment with elicitors such as chitin fragments and flagellin (Peck et al., 2001). 
Presumably pathogenesis involves reallocation of resources to support the plant's defenses or growth of the invading pathogen. For example, transcriptome analyses have shown that infection results in dramatic, global changes in metabolism (Scheideler et al., 2002). Although their adaptive significance and specificity are still unclear, considerable evidence suggests there are regulatory links between carbohydrate metabolism and responses to pathogens (Herbers et al., 1996; Mathews, 1981). Susceptibility to pathogen infection depends on the sugar content of leaves; virus infection can alter carbohydrate content and sugar translocation; and, sugars can induce expression of defense-related genes. We found that antisense and sense GBP transformants exhibit leaf curling, decreased starch, fructose and sucrose in the leaves affected, the formation of HR-like lesions, and the induction of markers for HR. Similarly, AKR2 antisense transformants show HR-like lesions, induction of markers for HR, and increased resistance to the pathogen Pseudomonas syringae pv. maculicola (Yan et al., 2002). Leaf curling also has been reported for transgenic tobacco expressing mannitol-1-phosphate dehydrogenase and myo-inositol O-methyltransferase, which show reduced accumulation of soluble sugars in apical parts of the plant (Sheveleva et al., 2000). Constitutive expression of apoplastic and vacuolar isoforms of yeast invertase in tobacco leads to increased sugar and starch accumulation, leaf curling, chlorosis, formation of HR-like lesions, the activation of SAR and increased resistance to potato virus Y (Herbers et al., 1996; Sonnewald et al., 1991). Leaf curling, chlorosis, accumulation of soluble sugars, HR-like lesions, and induction of an HR-marker are also characteristic of antisense transformants of tobacco deficient in the sucrose $/ \mathrm{H}^{+}$-symporter $\mathrm{NtSUT1}$, which is required for sugar export from tobacco leaves (Bürkle et al., 1998; Herbers et al., 1996). Interestingly, the soybean PANKs AX306543 and AX306545 have been annotated as proteins interacting with soybean SUT1 (Adape et al., 2003) suggesting that PANKs could regulate SUT1 activity.

A role for PANKs in carbohydrate metabolism is also consistent with our finding that antisense and sense GBP transformants can generate graft transmissible signals that move acropetally to sink leaves and induce leaf curling. Although the nature of these signals is still not known, it is plausible

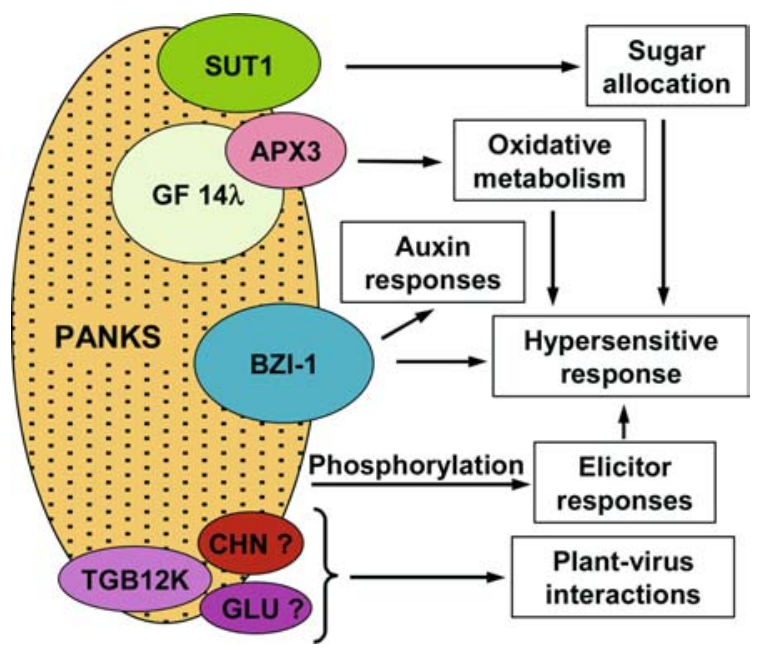

Figure 8. Schematic representation of known interactions between PANKs and other proteins. The model is based on the assumption that PANKs in different species are multivalent with similar binding properties. Likely functions of PANKs and their binding partners are indicated. Question marks indicate uncertainty about the robustness of an interaction in vivo.

that sugar transport through the phloem is altered resulting in disturbances in carbohydrate metabolism of target leaves and, hence, leaf curling.

\section{A working hypothesis: PANKs link carbohydrate metabolism and defense responses}

Our working hypothesis, schematized in Figure 8, is that PANKs are multifunctional proteins important for induction of defense responses that link these responses to carbohydrate metabolism. The most direct support for this hypothesis is the finding that transformants altered in PANK expression (GBP/TIP and AKR2), invertase expression, and SUT1 expression exhibit a similar syndrome characterized by disturbances in carbohydrate metabolism, formation of HR-like lesions, and activation of defense-related gene expression. This hypothesis is also consistent with the finding that proteins interacting with PANK family members have a role in regulating HR or carbohydrate metabolism.

\section{Acknowledgments}

We thank Leslie Friedrich, Syngenta Biotechnology, Research Triangle Park NC for the GLU III transformants; Daniel Hess and Anne Ulvestad 
for mass spectroscopy and 2D-PAGE; Grit Laue, Syngenta AG, Basel, Switzerland for gas-chromatographic measurements of metabolites; Markus Briker for expert care of plants; Jörg Felix, Ueli Klahre, and Azeddine Si-Ammour for helpful comments; and, the Novartis Research Foundation for financial support.

\section{References}

Adape, M.J., Elmer, A.M., Chao, W.S. and Grimes, H.D. 2003. Identification and characterization of a sucrose transporter isolated from the developing cotyledons of soybean. Arch. Biochem. Biophys. 409: 243-250.

Andrade, M.A., Perez-Iratxeta, C. and Ponting, C.P. 2001. Protein repeats: structures, functions, and evolution. J. Struct. Biol. 134: 117-131.

Becker, D. 1990. Binary vectors which allow the exchange of plant selectable markers and reporter genes. Nucl. Acids Res. 18: 203-

Beffa, R.S., Hofer, R.-M., Thomas, M. and Meins, F. Jr. 1996. Decreased susceptibility to virus disease of $\beta$-1,3-glucanasedeficient plants generated by antisense transformation. Plant Cell 8: 1001-1011.

Beffa, R.S., Neuhaus, J.-M. and Meins, F. Jr. 1993. Physiological compensation in antisense transformants: specific induction of an ersatz glucan endo-1,3- $\beta$-glucosidase in plants infected with necrotizing viruses. Proc. Natl. Acad. Sci. USA 90: 8792-8796.

Bourque, J.E. 1995. Antisense strategies for genetic manipulation in plants. Plant Sci. 105: 125-149.

Bucher, G.L., Tarina, C., Heinlein, M., Di Serio, F., Meins, F. Jr. and Iglesias, A. 2001. Local expression of enzymatically active class I $\beta$-1,3-glucanase enhances symptoms of TMV infection in tobacco. Plant J. 28: 361-369.

Bürkle, L., Hibberd, J.M., Quick, W.P., Kuhn, C., Hirner, B. and Frommer, W.B. 1998. The $\mathrm{H}^{+}$-Sucrose Cotransporter NtSUT1 Is Essential for Sugar Export from Tobacco Leaves. Plant Physiol. 118: 59-68.

Caspar, T., Huber, S. C., and Somerville, C. 1985. Alterations in growth, photosynthesis, and respiration in a starchless mutant of Arabidopsis thaliana (L.) deficient in chloroplast phosphoglucomutase activity. Plant Physiol. 79: 11-17.

Datta, S.K. and Muthukrishnan, S. 1999. Pathogenesis-Related Proteins in Plants. CRC Press LLC, Boca Raton, FL.

Felix, G. and Meins, F. Jr. 1986. Developmental and hormonal regulation of $\beta$-1,3-glucanase in tobacco. Planta 167: 206-211.

Fridborg, I., Grainger, J., Coleman, M., Findlay, K. and Angell, S. 2003. TIP, A novel host factor linking callose degradation with the cell-to-cell movement of Potato virus $X$. Mol. Plant-Microbe Interact. 16: 132-140.

Friedrich, L., Lawton, K., Ruess, W., Masner, P., Specker, N., Gut-Rella, M., Meier, B., Dincher, S., Staub, T., Uknes, S., Métraux, J.-P., Kessmann, H. and Ryals, J. 1996. A benzothiadiazole derivative induces systemic acquired resistance in tobacco. Plant J. 10: 61-70.

Glazebrook, J., Chen, W., Estes, B., Chang, H.-S., Nawrath, C., Métraux, J.-P., Zhu, T. and Katagiri, F. et al. 2003. Topology of the network integrating salicylate and jasmo- nate signal transduction derived from global expression phenotyping. Plant J. 34: 217-228.

Hames, B.D. 1998. Gel Electrophoresis of Proteins - a Practical Approach. Oxford University Press, Oxford.

Hammond-Kosack, K. and Parker, J. 2003. Deciphering plantpathogen communication: fresh perspectives for molecular resistance breeding. Current Opin. Biotechnol. 14: 177-193.

Herbers, K., Meuwly, P., Frommer, W.B., Métraux, J.-P. and Sonnewald, U. 1996. Systemic acquired resistance mediated by the ectopic expression of invertase: possible hexose sensing in the secretory pathway. Plant Cell 8: 793-803.

Horsch, R., Fry, J., Hoffman, N., Neidermeyer, J., Rogers, S. and Fraley, R. 1988. Leaf disc transformation. In: S. Gelvin, and R. Schilperoort (Eds.), Plant Molecular Biology Manual, A5, Kluwer Academic, Dordrecht, pp. 23-50.

Iglesias, A. and Meins, F. Jr. 2000a. Vacuoles and plant defense. In: D.G. Robinson and J.C. Rogers (Eds.), Vacuolar Compartments, Sheffield Academic Press, Sheffield, pp. $112-132$.

Iglesias, V.A. and Meins, F. Jr. 2000b. Movement of plant viruses is delayed in a $\beta$-1,3-glucanase-deficient mutant showing a reduced plasmodesmatal size exclusion limit and enhanced callose deposition. Plant J. 21: 157-166.

Kaufmann, E., Giesler, N. and Weber, K. 1984. SDS-PAGE strongly overestimates the molecular masses of the neurofilament proteins. FEBS Lett. 170: 81-

Keefe, D., Hinz, U. and Meins, F. Jr. 1990. The effect of ethylene on the cell-type-specific and intracellular localization of $\beta$-1,3-glucanase and chitinase in tobacco leaves. Planta 182: 43-51.

Krieg, J., Hartmann, S., Vicentini, A., Glasner, W., Hess, D., and Hofsteenge, J. 1998. Recognition signal for C-mannosylation of Trp-7 in RNase 2 consists of the sequence Trp-X-XTrp. Mol. Biol. Cell 9: 301-309.

Kuhlmann, M., Horvay, K., Strathmann, A., Heinekamp, T., Fischer, U., Bottner, S. and Droge-Laser, W. 2003. The alpha-helical D1 domain of the tobacco bZIP transcription factor BZI-1 interacts with the ankyrin-repeat protein ANK1 and is important for BZI-1 function, both in auxin signaling and pathogen response. J. Biol. Chem. 278: 87868794.

Kunz, C., Schöb, H., Stam, M., Kooter, J. M. and Meins, F. Jr. 1996. Developmentally regulated silencing and reactivation of tobacco chitinase transgene expression. Plant J. 10: $437-450$.

Kunze, I., Kunze, G., Bröker, M., Manteuffel, R., Meins, F. Jr. and Müntz, K. 1998. Evidence for secretion of vacuolar $\alpha$-mannosidase, class I chitinase, and class I $\beta$-1,3-glucanase in suspension cultures of tobacco cells. Planta 205: 92-99.

Leubner-Metzger, G. 2003. Functions and regulation of $\beta$-1,3glucanases during seed germination, dormancy release and after-ripening. Seed Sci. Res. 13:

Leubner-Metzger, G. and Meins, F. Jr. 1999. Function and regulation of plant $\beta$-1,3-glucanases (PR-2). In: S.K. Datta and S. Muthukrishnan (Eds.), Pathogenesis Related Proteins in Plants, CRC Press, Boca Raton, FL, pp. 49-76.

Mathews, R.E.F. 1981. Plant Virology. Academic Press, New York.

Müller, J., Mohr, U., Sprenger, N., Bortlik, K., Boller, T. and Wiemken, A. 1999. Pool sizes of fructans in roots and leaves of mycorrhizal and non-mycorrhizal barley. New Phytol. 142: 551-559.

Neuhaus, J.-M., Ahl-Goy, P., Hinz, U., Flores, S. and Meins, F. Jr. 1991. High-level expression of a tobacco chitinase gene 
in Nicotiana sylvestris. Susceptibility of transgenic plants to Cercospora nicotianae infection. Plant Mol. Biol. 16: 141-151.

Payne, G., Ward, E., Gaffney, T., Ahl-Goy, P., Moyer, M., Harper, A., Meins, F. Jr. and Ryals, J. 1990. Evidence for a third structural class of $\beta-1,3$-glucanase in tobacco. Plant Mol. Biol. 15: 797-808.

Peck, S.C., Nühse, T.S., Iglesias, A., Meins, F. and Boller, T. 2001. Directed proteomics identifies a plant-specific protein rapidly phosphorylated in response to bacterial and fungal elicitors. Plant Cell 13: 1467-1475.

Pietrzak, M., Shillito, R.D., Hohn, T. and Potrykus, I. 1986. Expression in plants of two bacterial antibiotic resistance genes after protoplast transformation with a new plant expression vector. Nucl. Acids Res. 14: 5857-5868.

Rechsteiner, M. and Rogers, S.W. 1996. PEST sequences and regulation by proteolysis. Trends in Biochem. Sci. 21: 267-271.

Ryals, J.A., Neuenschwander, U.H., Willits, M.G., Molina, A., Steiner, H.-Y. and Hunt, M.D. 1996. Systemic acquired resistance. Plant Cell 8: 1809-1819.

Ryals, J., Ward, E. and Métraux, J.-P. 1992. Systemic acquired resistance: an inducible defense mechanism in plants. Symp. Soc. Exptl. Biol. 49: 205-229.

Sambrook, J. and Russell, D.W. 2000. Molecular Cloning. A Laboratory Manual. Cold Spring Harbor Lab. Press, Cold Spring Harbor, NY.

Scheideler, M., Schlaich, N.L., Fellenberg, K., Beissbarth, T., Hauser, N.C., Vingron, M., Slusarenko, A.J., and Hoheisel, J.D. 2002. Monitoring the switch from housekeeping to pathogen defense metabolism in Arabidopsis thaliana using cDNA arrays. J. Biol. Chem. 277: 10555-10561.
Sheveleva, E.E., Jensen, R.G. and Bohnert, H.J. 2000. Disturbance in the allocation of carbohydrates to regenerative organs in transgenic Nicotiana tabacum L. J. Exp. Bot. 51: $115-122$.

Shinshi, H., Mohnen, D. and Meins, F. Jr. 1987. Regulation of a plant pathogenesis-related enzyme: inhibition of chitinase and chitinase mRNA accumulation in cultured tobacco tissues by auxin and cytokinin. Proc. Natl. Acad. Sci. USA 84: 89-93.

Sonnewald, U., Brauer, M., von Schaewen, A., Stitt, M. and Willmitzer, L. 1991. Transgenic tobacco plants expressing yeast-derived invertase in either the cytosol, vacuole or apoplast: a powerful tool for studying sucrose metabolism and sink/source interactions. Plant J. 1: 95-106.

Tsugita, A. and Kamo, M. 1999. 2-D electrophoresis of plant proteins. Methods Mol. Biol. 112: 95-97.

Vögeli-Lange, R., Hansen-Gehri, A., Boller, T. and Meins, F. Jr. 1988. Induction of the defense-related glucanohydrolases, $\beta$-1,3-glucanase and chitinase, by tobacco mosaic virus infection of tobacco leaves. Plant Sci. 54: 171-176.

Ward, E.R., Uknes, S.J., Williams, S.C., Dincher, S.S., Wiederhold, D.L., Alexander, D.C., Ahl-Goy, P., Métraux, J.-P. and Ryals, J.A. 1991. Coordinate gene activity in response to agents that induce systemic acquired resistance. Plant Cell 3: 1085-1094.

Yan, J., Wang, J., and Zhang, H. 2002. An ankyrin repeatcontaining protein plays a role in both disease resistance and antioxidation metabolism. Plant J. 29: 193-202.

Zhang, H., Scheirer, D.C., Fowle, W.H. and Goodman, H.M. 1992. Expression of antisense or sense RNA of an ankyrin repeat-containing gene blocks chloroplast differentiation in arabidopsis. Plant Cell 4: 1575-1588. 